\title{
RELEVANT KNOWLEDGE AS AN INSTRUMENT FOR EXPATRIATE MANAGER'S ACTIONS
}

\author{
Davor Vlajčić5
}

UDC / UDK: 005.94:005.96:334.726

JEL classification / JEL klasifikacija: F22, F23

DOI: https://doi.org/10.22598/pi-be/2020.14.2.27

Original scientific paper / Izvorni znanstveni rad

Received / Primljeno: May 21, 2020 / 21. svibnja, 2020

Accepted for publishing / Prihvaćeno za tisak: September 28, 2020 / 28. rujna 2020.

\section{Summary}

Purpose: This paper examines the philosophy behind multinational companies' global knowledge flows, highlighting links between external actors' knowledge and expatriate managers' actions. Applying philosophical pragmatism as a theoretical background, expatriate managers' perception of external actors' knowledge is presented as a tool enabling successful knowledge transfer.

Design/methodology/approach: Data obtained via a survey on a sample of expatriate managers in Croatia is used. Using a partial least square structural equation modeling method, the correlations between external actors' impact and subsidiary investment and headquarter benefits are explored.

Findings and implications: Expatriate managers believe that headquarters benefit from a stronger impact of external actors on subsidiaries and an increase in subsidiaries' internal investment. Our findings direct managers towards the harmonization of their priorities, highlighting the importance of inter- and intraorganizational agreements, suggesting that financial means should be directed towards widening internal knowledge bases and exploiting the potential of external knowledge.

Limitations: Expats relevance perception priorities may be disrupted when headquarters impose performance evaluation criteria. This paper is also subject to expatriate managers' experience limitations, which decreases their likelihood of recognizing relevant knowledge.

Originality/value: Focusing on the psychology of expatriate managers, this paper introduces philosophical pragmatism as a theoretical framework underpinning successful knowledge transfer actions. Originating from pragmatism, successful actions are made through a manager's perception of relevant knowledge. Expatriate managers'

${ }^{5}$ Davor Vlajčić, PhD, Assistant professor, University of Zagreb Faculty of Economics and Business, Email: dvlajcic@net.efzg.hr 
actions are thus not passive reflections of their reality, but rather the result of their perception of relevant knowledge.

Keywords: Pragmatism, Subsidiary, Headquarters, Expatriate managers, Relevant knowledge, Perception.

\section{INTRODUCTION}

Multinational companies (MNCs), and their importance in economic activities, have increased in number significantly since the 1950s (Pudelko \& Harzing, 2008; Epstein, 2019; Kostova, Marano, \& Tallman, 2016). Internal organizations' settings, their renewed conceptualization, and their understanding of units all significantly impact international business and strategic management literature (Brewer \& Staves, 2014; Buckly \& Strange, 2011; Birkinshaw \& Hood, 1998; Cantwell \& Mudambi, 2005). MNCs use specific assets and knowledge as fundamental resources with which they can perform competitively across dispersed foreign subsidiaries (Mudambi, Pedersen, \& Andersson, 2014; Mikalef \& Pateli, 2017; Windsperger \& Gorovaia, 2011). However, they are facing strong challenges when it comes to maintaining them. Complexity, volatility, uncertainty, and information accessibility are changing social and business environments, and the traditional relationships between units are being reorganized (Chiao \& Ying, 2013). Tapping into local external networks, subsidiaries organize independent interorganizational arrangements and, assimilating their knowledge, develop new technological and organizational innovations (Simao \& Franco, 2018; Cricelli \& Grimaldi, 2010; Porter \& Sölvell, 1998; Ryan et al., 2018). External knowledge assimilation demands Research \& Developmenet expertise and managerial capabilities in order to increase subsidiaries sourcing and combinative capabilities (Phene \& Almeida, 2008). This becomes necessary by virtue of the uniqueness, complexity, and ambiguousness of the business environment, which creates difficulties (Szulanski, 1996) and incurs costs (Teece, 1977) throughout the knowledge transfer process. By sourcing and recombining external knowledge, subsidiaries embed acquired knowledge in bundles of routines, strongly intertwined with the previous subsidiaries' and MNCs' routines (Foss \& Pedersen, 2002), making external knowledge universally applicable. The management of sourcing and combinative capabilities demands the efforts of actors, such as consultants or, in the case of subsidiaries, expatriate managers. Originating from a global network of MNCs, expatriate managers are aware of current MNCs' global goals and strategies. If successful, expatriate managers have the freedom to operate subsidiaries' current business processes, and have the ability to attempt new initiatives (Dörrenbächer \& Gammelgaard, 2016). MNCs' goals, their strategy awareness, and their freedom to operate present basic prerequisites for expatriates when it comes to identifying foreign opportunities (Fang et al., 2010) and, in particular, foreign environment knowledge. Managing financial assets independently, with the exception of only significantly larger investment demands that require the approval of headquarters (Yang, Mudambi, \& Meyer, 2008), expatriate managers develop the internal capabilities necessary for capturing foreign opportunities. Whether they consider knowledge sharing 
to be part of their everyday assignment, output of their psychological and social capital, or a pressure from headquarters, managing it independently is a big responsibility which poses a difficult challenge for expatriate managers.

Numerous researchers have demonstrated ambiguous findings with regards to the importance of intra-organizational knowledge transfer and expatriate mangers' roles in the knowledge transfer process. This research focuses on the psychological components of the observed unit - the expatriate manager. Although prior research has often focused on different expatriate managers' psychological components, such as motivation (Sanchez-Vidal, Sanz-Valle, \& Barba-Aragon, 2018), individual readiness (Lee \& Kartika, 2014), managerial attention (Kumar, 2013), etc., there is a lack of research when it comes to expatriate managers' attitudes related to their actions, which are considered to be more than just a passive reflection of reality (Cojanu, 2014). This study examines the philosophy behind MNCs' global knowledge flow. Using expatriate managers, the links between external actors' knowledge and expatriate managers' actions are highlighted. Applying philosophical pragmatism as a theoretical background, expatriate managers' knowledge perception is presented as a tool allowing successful knowledge transfer actions to be made. Originating from pragmatism, successful actions are made using managers' perceptions of relevant knowledge. An individual will decide that a piece of knowledge is relevant if he perceives that the impact of that knowledge on his existing knowledge base is high, and the effort needed to process this knowledge is low (Schulz, 2003). In this way, expatriate managers' actions are not just passive reflections of their reality, but rather the result of their relevant knowledge perception. In the context of this research, an expatriate manager finds knowledge relevant if he perceives there to be a strong impact of the external knowledge on a subsidiary's existing knowledge base, and highly developed internal re-combinative capabilities. If knowledge is perceived to be relevant, this knowledge becomes an expatriate managers' tool and instrument for action and problem solving. The headquarters benefit from expatriate managers' actions, given their main role as a knowledge transfer agent. This paper's theoretical contribution emerges from the use of a completely new philosophical approach when describing MNCs' knowledge management operations, confirming the thesis that expatriate managers' actions are not passive reflections of reality, but rather the result of expatriate managers' relevant knowledge perception. Empirical findings lead expatriate managers, as well as headquarters, towards a better understanding of the importance of inter- and intra-organizational agreements. Furthermore, in an attempt to understand the importance of the harmonization of priorities for expatriate managers as well as headquarters, this research argues that MNCs should invest in the profiling of expatriate managers, educating them about global network relevance priorities before assignments. This research emphasizes that expatriate managers should focus their efforts on the development of inter-organizational agreements with external partners, and should direct financial means towards widening their internal knowledge base in order to increase a subsidiary's absorptive capacity and its ability to exploit the potential of external knowledge.

This introduction is followed by an explanation of the paper's theoretical development, which will serve as a backbone for the following section: hypothesis 
development. After this, in the empirical analysis, this paper will seek to prove the developed hypothesis, followed by a discussion and conclusion.

\section{LITERATURE REVIEW}

\subsection{Subsidiaries as knowledge creators}

Maintaining a competitive advantage can be a difficult task, dependent in large on the relationship that the headquarters and the subsidiary nurture (Harzing \& Pudelko, 2014). Despite the principal/agent relationship sustained, strong environmental pressures, changes in technology, customer preferences, and regulatory institutions bring about disturbances in the traditional headquarters/subsidiary relationship (Chiao \& Ying, 2013). Conventional and reverse knowledge transfer can no longer be clearly distinguished, as the former is a teaching process and the latter involves persuasion (Yang, Mudambi, \& Meyer, 2008). According to Chiao and Ying (2013), newly developed MNCs' complex and less hierarchical structures have moved subsidiaries from the role of exploitation to value-added creators. This new and complicated system follows the reduction of headquarters' authority and power (Forsgren, Holm, \& Johanson, 2005), making subsidiaries semiautonomous (Bouquet \& Birkinshaw, 2008). According to some researchers, this depends on the resources and capabilities of a subsidiary, as well as its initiatives. The momentum of the subsidiary's role changes when they take on a more active role in supporting MNCs' innovation activities, mostly due to the growing impact of external factors. Subsidiaries build their own knowledge base, embedded in their internal and external networks (Garcia-Pont, Canales, \& Noboa, 2009; Yamin \& Andersson, 2011). The intervention of these two processes increases the likelihood of a positive contribution towards a global network resource base. Developing a business relationship with a number of external parties (Andersson, Dahlin, \& Ekman, 2014), which allows for the assessment of external resources, only works if strong partner relationships with other intra-organizational units are developed and strategies are compiled (Michailova \& Minbaeva, 2012). External networks that surround subsidiaries are seen to be strategic sources of knowledge (Figueiredo, 2011) and relational embeddedness, in that networks allow for MNCs competence development (Andersson, Björkman \& Forsgren, 2005). By embedding itself in an external environment, a subsidiary faces numerous local actors, among which emphasis is put on customers, suppliers, competitors, etc. Furthermore, besides external parties' knowledge, subsidiaries also benefit indirectly, using resources and technological expertise that external parties have pooled from their networks (Mesquita, Anand, \& Brush, 2008). However, direct relationships with local actors is only one part of the puzzle, with adjustment to the local environment contributing to the complete subsidiary knowledge creation jigsaw. Firms use their external environment as a platform and leverage its characteristics. Availability and quality of business professionals (Syed, Hazboun, \& Murray, 2014; Shaffer et al., 2016), government support (Davis \& Meyer, 2004), the legal environment (Dhanaraj \& Beamish, 2009), the existence of research institutions (Santangelo, Meyer, \& Jindra, 2016), and competition (Meyer and Estrin, 2014) all become sources of knowledge inputs and create fertile ground for knowledge creation. 
However, as a result of its development with local actors, using distant platforms, this knowledge can be characterized by its uniqueness and, according to Asmussen, Foss, and Pedersen (2013), might possess low fungibility and low congruity in comparison to other units. Furthermore, the same authors emphasize that, with the accumulation of this kind of knowledge in a subsidiary, its value for other parts of the MNC reduces. According to Rugman and D'Cruz (2000), the coordination of knowledge based on external network relationships raise huge governance costs. In short, where the impact of the aforementioned knowledge decreases, while the effort needed to process mentioned knowledge increases, it seriously sheds light on the relevance of external knowledge.

\subsection{Expatriate managers: roles and perceptions}

Making external knowledge universally applicable demands the effort of specific actors. According to Kusumato (2014), to re-establish cooperation, as well as compliance with strategies and policies, MNCs deploy intentional assignees - expatriate managers - in subsidiaries. They are given the role of "agents of control", and occupy headquarters status within the subsidiary, thereby removing the headquarters from the centralized activities equation. Expats have been previously exposed to the MNCs' global network, gaining familiarity with the MNCs' global aims (Koo Moon, Kwon Cho, \& Shik Jung, 2012). According to the contingency theory, expatriate managers must first act as localizers in order to become globalizers, i.e. adjust to their new local environment in order to implement the acquired knowledge within a pre-existing base. Numerous researchers (Kobrin, 1988; Gaur, Delios, \& Singh, 2007; Chang, Gong, \& Peng, 2012; Peltokorpi \& Vaara, 2014) have observed that expatriate managers act as knowledge carriers; individuals who, by extracting knowledge from their external environment, integrate knowledge, values, and know-how to a subsidiary and to the rest of an MNCs' global network (Kusumato, 2014). It follows then that the expatriate managers' task is to keep external and internal embeddedness in balance. Continuing their actions determines the mode of knowledge acquisition, which implies that knowledge acquisition could be the result of direct managerial perception (Schulz, 2003). If successful, expatriate managers are given the freedom to operate a subsidiary's business processes (Dörrenbächer \& Gammelgaard, 2016). This increases an expatriate's possibility (Ferner, Edwards, \& Tempel, 2012) of identifying, acquiring, and sharing foreign environmental knowledge (Levy et al., 2007). Early research, which has recognized that perception is an important determinant, concludes that managers' perceptions of their external environment are dependent on their firm's strategic orientation (Perlmutters, 1969). This fits perfectly with this paper's research focus, given that, according to Kusumato (2014), it is expatriate managers who re-establish cooperation, as well as facilitate the compliance of strategies and policies, i.e. their perception of their external environment is heavily influenced by subsidiaries' strategic goals. The intensity of the influence that a strategy has on expat perception depends largely on the manager's global mindset (Gupta \& Govindarajan, 2002; Evans, Rees, \& Edwards, 2017). 


\section{HYPOTHESIS DEVELOPMENT}

Long-lasting complex and intimate relationships with external actors shape a subsidiary's knowledge base and present the conditions required for technological and organizational innovation (Andersson, Forsgren, \& Holm, 2002; Michailova \& Minbaeva, 2012; Asmussen, Foss, \& Pedersen, 2013). It is commonly believed that cooperation with local actors, customers, suppliers, and distributors, along with the successful capturing of their new demands, brings about new business initiatives (Yamin \& Andersson, 2011; Michailova \& Minbaeva, 2012), while the lack of it, and the process of disregarding this knowledge, can result in a subsidiary's failure (Fang et al., 2010). In numerous pieces of research (Fang et al., 2010; Bartlett \& Rangan, 1992; Bartlett \& St. George, 1998), expatriate managers have emphasized that customers are the leading external determinants of a subsidiary's business processes. According to Lim and Yeo (2015), research conducted on subsidiaries in Korea has shown that managers' evaluation of customers' new demands can result in the successful capturing of new market opportunities and new product development. Customers are shown to be an important source of local knowledge (Fang et al., 2010), as confirmed in the research of Bartlett and Rangan (1992), who proved that disregarding customers' knowledge resulted in KFC's failure within the Hong Kong market. Expatriate managers agree that swiftly replicating firm's traditional practices, without first gaining sufficient knowledge of the local market's distinct characteristics and customers consumption habits (Bartlett \& Rangan, 1992), was a bad decision. The same authors, in contrast with previous findings, observed successful cooperation with local retailers and consumers using Aspire, designed by a local Silicon Valley firm called Frog Design. However, cooperation with customers is not the only prerequisite for subsidiary success. In the research of Tseng and Chen (2014), expatriate managers stressed that suppliers were important contributors when it came to competence development. Suppliers collaborate by pooling resources and technological expertise. Sharing specialized knowledge enables suppliers' partners to learn from each other, leverage their partners' expertise, and create collective knowledge, resulting in superior solutions for customers (Mesquita, Anand, and Brush, 2008). For example, in the semiconductor industry, it is increasingly common for suppliers to develop new products or production processes for original equipment manufacturers (OEMs) by sharing technological knowledge. Furthermore, same authors in their research of links between subsidiary and local supplier, the asset-specific investment and relational capital of local suppliers were shown to be positively associated with a subsidiary's technological capability. However, when positively observing external organizations' implications, Holl and Rama (2014) pointed out that foreign subsidiaries show less of a propensity for external technology sourcing via R\&D when outsourcing from independent firms in their host country, for international R\&D outsourcing, and for international cooperation in innovations.

The variety of external conditions can leave traces on expatriate managers' mindsets, pulling them closer to identification with parent, or leaning more on the host market issues (Evans, Rees, \& Edwards, 2017). However, despite managers' global mindset standing, knowledge transfer is always their main focus. According to Ghobadi 
and Mathiassen (2016), differences in subsidiaries' managers, as well as local and expatriate managers' (Darawong, Igel, \& Badir, 2016), perceptions can lead to the most effective form of knowledge transfer through agreements made regarding potential barriers and misunderstandings. Furthermore, perceiving this to be an important performance evaluation criterion, expatriates' efforts to share knowledge increases (Björkman, Barner-Rasmussen, \& Li, 2004), seeing knowledge transfer simply as a natural expectation, or part of the job. However, expatriate managers perception, as previously stated, depends largely on corporate culture and attitudes towards headquarters (Chang, Gong, \& Peng, 2012). Furthermore, expatriate managers sometimes perceive reciprocation to be of paramount importance (Minbaeva \& Michailova, 2004; Serenko \& Bontis, 2016). The genuine perception of expatriate managers is that subsidiaries and headquarters should exchange knowledge because, in doing so, they can share their knowledge bases and can evaluate the impact of the knowledge they might send. According to Levin and Cross (2004), reciprocity also reinforces trust between units. Even in a case of present reciprocity, willingness to share knowledge is necessary, but is not always a sufficient prerequisite for successful transfer. According to Riusala and Smale (2007), expatriate managers perceive that their willingness must be accompanied by the absorptive capacity of headquarters' units. Similarly, the research of Oddou, Osland, and Blakeney (2009) has shown that, next to the absorptive capacity of a unit, expatriate managers also perceive their position of power to be necessary for successful knowledge transfer. These findings go hand in hand with previous research conducted by Riusala and Suutari (2004) and Riusala and Smale (2007), who concluded that expatriate managers perceived their role in this process to be autonomous, multifaceted, crossfunctional, and personally challenging. Continuing this research, Lee and Kartika (2014) found that expatriate managers emphasized the adjustment of their general traits as having a positive influence on knowledge transfer. Among them, Welch and Welch (2008) distinguished language skills, frequency of contact, communication, motivation, and trust. In research conducted by Sitar and Mihelič (2018), expatriate managers perceived their personal capital, such as positive psychological capital and social capital, as facilitators of knowledge transfer.

Recent history has indicated that compatibility is a crucial condition for knowledge and information exchange (Schulz, 2003). Among the first fields to acknowledge compatibility as a prerequisite to this was psychology (Milgram, Sabini, \& Silver, 1992), in which a positive correlation between compatibility and attraction was detected. A similar effect in business literature was detected by Palich and Gomez-Mejia (1999), who found that efficiency in international business units grows with a higher degree of relatedness. High levels of similarity between the sender and receiver, in terms of knowledge, is often seen as conducive to knowledge transfer, which has been confirmed in research conducted by Anzola Román et al. (2019). These researchers found that companies will collaborate intensively throughout the whole transfer process if technological bases matchup tightly. However, some authors argue against this finding. According to Asmussen, Foss, and Pedersen (2013) neither a high nor a low level of similarity is associated with a high level of knowledge transfer. If the knowledge of the subsidiary is too similar to the knowledge held by the $\mathrm{MNC}$, it may become redundant to 
the MNC's context and be associated with a diminished level of potential innovation, inhibiting knowledge transfer (Asmussen, Foss, \& Pedersen, 2013). These findings are consistent with the idea of dual institutional pressures (Kostova \& Zaheer, 1999), which force the subsidiary to balance its similarity to the host country's environment with its similarity to the MNC's internal environment. Contrary to this, Inkpen and Dinur (1998) emphasized that inter-unit knowledge transfers in MNCs were more successful when subunits operated in similar contexts as this leads to greater overlaps in terms of knowledge bases, requires less adjustment of the transferred knowledge, and thereby alleviates knowledge transfers. This is achieved by widening internal knowledge boundaries, increasing the probability of overlaps with the external actor's knowledge. Ho and Ganesan (2013) refer to this as "knowledge base compatibility". Phene and Almeida (2008) argued that managerial capabilities that permit the integration and recombination of knowledge are combinative capabilities. This can be achieved through investment into the development of new competences. According to the research of Cuervo-Cazurra, Mudambi, and Pedersen (2019), subsidiaries almost always have authority over their management of resources, which mostly dictates their financial resources and their ability to invest in new projects within the subsidiary's existing charter (Galunic \& Eisenhardt, 1994).

Their awareness of global strategies allows expatriate managers to identify global needs (Levy et al., 2007). However, the abundance of subsidiaries, interorganizational arrangements, and location specificities, sets challenges when it comes to distinguishing important knowledge from less important knowledge. In other words, these challenges direct expatriate managers' perceptions (Schulz, 2003) when deciding which knowledge might be beneficial for their MNCs' global knowledge base. This research, similar to that of Schulz (2003), focuses on individual cognitive schemes and their perceptions, because a manager's perception frames their decisions and actions. Individuals perceive knowledge to be relevant if they perceive that the impact of the knowledge on an existing knowledge base is high. The strong impact of external organizations on subsidiary knowledge bases has been proven in numerous pieces of research (Yamin \& Andersson, 2011; Lim, \& Yeo, 2015; Tseng \& Chen, 2014), all of which agree that this expands a subsidiary's knowledge base. A strong impact on an existing knowledge base is not the only prerequisite for knowledge to be considered relevant, individuals find knowledge to be relevant if they perceive that the effort needed to process this knowledge is low. Scholarly literature demonstrates that a greater overlap of knowledge bases, i.e. knowledge compatibility, lowers the effort needed to process knowledge (Anzola Román et al., 2019; Ho \& Ganesan, 2013), due to less of a need for adjustment. The compatibility of external actors' and subsidiaries' knowledge is achieved by investing in R\&D expertise and the development of managerial capabilities. As previously stated, these capabilities are a necessary condition of the integration and recombination of external knowledge in terms of routines, which are strongly intertwined with those of previous subsidiaries and MNCs. Acting as an agent of knowledge transfer in the subsidiary/headquarter relationship, expatriate managers find their ability to perceive relevant knowledge to be the source of their successful knowledge transfer actions, and headquarters benefit from this. 
Thus, we posit:

H1: Expatriate managers perceive that headquarters' benefits are positively correlated with the impact of an external organization on a subsidiary's knowledge base

H2: Expatriate managers perceive that headquarters' benefits are positively correlated with subsidiaries' internal investments

The above developed Hypothesis are presented in researched model which can be seen in Figure 1.

Figure 1. Research model

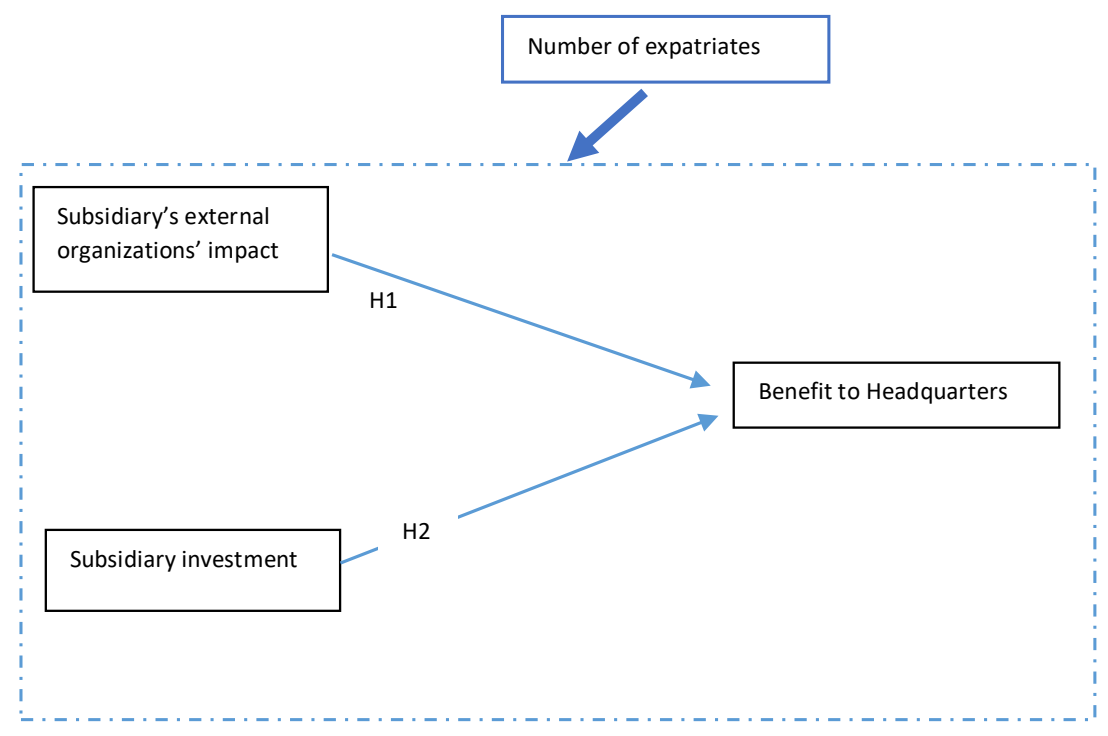

\section{RESEARCH METHOD}

\subsection{Sample}

Defined as knowledge "carriers" (Kusumato, 2014) and granted independence in decision making (Dörrenbächer and Gammelgaard, 2016), expatriate managers are ideal candidates for our research. In order to collect data, a standardized questionnaire was developed, written in English, and uploaded onto an online platform (Survey Monkey). The questionnaire was developed following an extensive literature review on expatriate managers and knowledge management, and feedback and recommendations 
from academics were included following a pre-test phase conducted on selected expatriate managers. Requests for participation in the questionnaire survey were made through personal contacts or by sending the questionnaire to subsidiaries' HR services. According to the Ministry of Internal Affairs (2014) the entire population of expatriate managers in Croatia totaled 841. 107 questionnaires were collected, representing 12.5\% of the population which, according to Yang et al. (2008), gave a sufficient response rate for further research. After data cleaning was conducted, 94 questionnaires were valid and further analysis could be conducted. Descriptive statistics of the respondents' demographics can be found in Table 1 .

Table 1. Descriptive statistics of the respondent's demographics

\begin{tabular}{|c|c|c|c|c|c|c|c|c|c|}
\hline \multicolumn{2}{|c|}{ Gender: } & \multicolumn{2}{|c|}{ Age: } & \multicolumn{2}{|c|}{ Education level: } & \multicolumn{2}{|c|}{$\begin{array}{l}\text { Number of } \\
\text { Expatriate } \\
\text { assignments } \\
\text { (6 month): }\end{array}$} & \multicolumn{2}{|c|}{$\begin{array}{l}\text { Time spent at } \\
\text { the subsidiary: }\end{array}$} \\
\hline $\begin{array}{l}\text { Femal } \\
\text { e }\end{array}$ & $\begin{array}{l}18.02 \\
\%\end{array}$ & $\begin{array}{l}25 \\
- \\
35\end{array}$ & $\begin{array}{l}25.50 \\
\%\end{array}$ & $\begin{array}{l}\text { High } \\
\text { school }\end{array}$ & $2.00 \%$ & 1 & $\begin{array}{l}33.00 \\
\%\end{array}$ & $\begin{array}{l}\text { Less } \\
\text { than } 6 \\
\text { month } \\
\text { s }\end{array}$ & $6.30 \%$ \\
\hline Male & $\begin{array}{l}79.78 \\
\%\end{array}$ & $\begin{array}{l}35 \\
- \\
45\end{array}$ & $\begin{array}{l}40.40 \\
\%\end{array}$ & $\begin{array}{l}\text { College } \\
\text { degree }\end{array}$ & $\begin{array}{l}20.00 \\
\%\end{array}$ & 2 & $\begin{array}{l}26.30 \\
\%\end{array}$ & $\begin{array}{l}6-12 \\
\text { month } \\
s\end{array}$ & $\begin{array}{l}15.90 \\
\%\end{array}$ \\
\hline & & $\begin{array}{l}45 \\
- \\
55\end{array}$ & $\begin{array}{l}26.50 \\
\%\end{array}$ & $\begin{array}{l}\text { Master' } \\
\text { s degree }\end{array}$ & $\begin{array}{l}60.10 \\
\%\end{array}$ & 3 & $\begin{array}{l}12.80 \\
\%\end{array}$ & $\begin{array}{l}12-24 \\
\text { month } \\
\mathrm{s}\end{array}$ & $\begin{array}{l}18.08 \\
\%\end{array}$ \\
\hline & & $\begin{array}{l}> \\
55\end{array}$ & $8.50 \%$ & $\begin{array}{l}\text { Doctora } \\
1 \text { degree }\end{array}$ & $\begin{array}{l}15.00 \\
\%\end{array}$ & 4 & $6.30 \%$ & $\begin{array}{l}24-36 \\
\text { month } \\
\text { s }\end{array}$ & $\begin{array}{l}13.80 \\
\%\end{array}$ \\
\hline & & & & Other & $3.00 \%$ & $\begin{array}{l}5 \text { or } \\
\text { mor } \\
\text { e }\end{array}$ & $\begin{array}{l}19.10 \\
\%\end{array}$ & $\begin{array}{l}\text { More } \\
\text { than } \\
36 \\
\text { month } \\
\mathrm{s}\end{array}$ & $\begin{array}{l}45.80 \\
\%\end{array}$ \\
\hline
\end{tabular}

\subsection{Operationalization of constructs}

Expats' perceptions on investment in internal competence development represents the independent variable used for this research. This variable was adopted from the research of Foss and Pedersen (2002) and was adjusted according to this paper's research objectives. Respondents were assessed in terms of their levels of investment in expanding their internal knowledge base in order to achieve knowledge compatibility and reduce the effort needed to adopt external knowledge over the last 3 years. 6 items were assessed: technical innovation capabilities, know-how in manufacturing, sales networks, brand names, research and development, and managerial capabilities. Expatriate managers' perceptions on the impact of external organizations on subsidiary competence development constituted the second independent variable. This variable measured expatriates' perceptions on the impact of external market customers, market suppliers, specific distributors, and specific research and development units, on a subsidiary. This 
research used headquarters' benefits as a dependent variable. Respondents evaluated the benefits made to headquarters as a result of transferred knowledge. This was measured by asking respondents to identify whether or not the transfer led to the following types of innovations: technical innovations, manufacturing innovations, sales and marketing innovations, financial innovations, management innovations, distribution innovations, product-related innovations, purchasing innovations, and human resource innovations. For control variables, a number of previous expatriate assignments - longer than 6 months - were used.

\subsection{Estimation procedure}

Statistical analysis was conducted using partial least square structural equation modeling (PLS-SEM) (Hair et al., 2017). Variance-based PLS algorithms were convenient to use due to the small number of observations, and because these did not require multivariate normality (Zhou et al., 2012). Additionally, this method of multivariate modeling is often used to test relationships between multiple dependent and independent variables, and for studies in the early stages of their theoretical development, using previously validated scales (Hernández-Perlines, Moreno-García, \& YañezAraque, 2016). Smart PLS v. 3.2.6. (Ringle, Wende, \& Will, 2017) was used to estimate measurements and structural model parameters (Tenenhaus et al., 2005) and ensure that the data fit the proposed theory evaluation of measurement models (Barclay, Higgins, \& Thomson 1995: Chin, 1998, Compeau \& Huff, 1999; Yi \& Davis, 2003; Afthanorhan, 2013). The confirmation of the path coefficients' statistical significance in the model was ensured through nonparametric bootstrapping with 5,000 replications, no sign changes, and the mean replacement of missing values in order to obtain standard errors (Henseler, Ringle, \& Sinkovics, 2009; Hernández-Perlines, Moreno-García, \& Yañez-Araque, 2016). In order to control the number of assignments, PLS-MGA was used.

\section{FINDINGS AND ANALYSIS}

\subsection{Analysis of measurement model results}

The observed constructs' characteristics are presented in Table 2. This table contains the correlation matrix, construct reliability and validity, and discriminant validity, which together evaluate internal consistency and reliability. The constructs' unidimensionality and high internal consistency are presented with Cronbach's Alpha's levels. According to Kline (2011), values above 0.7 constitute satisfactory levels. Furthermore, unidimensionality and high internal consistency were confirmed through a composite reliability indicator which, for all constructs, was above 0.8 and below 0.95 , which is acceptable, according to Nunnally and Bernstein (1994). The convergence validity of all constructs is presented through an average variance extracted (AVE) indicator. This indicator shows how much of the latent constructs' variance is explained by the indicators. According to Hair et al. (2010), the recommended values are above 0.5, which this research model satisfies. The model's discriminant validity indicator is based on AVE. According to Fornell and Larcker (1981), correlations between each pair of 
latent constructs must not exceed the square root of each construct's AVE, which this model satisfies. A common critique of the variance-based technique is that it does not contain adequate global measures concerning the goodness of model fit. However, with a prediction in focus, rather than explanatory modeling, authors such as Hair et al. (2017) and Henseler and Sarstedt (2013) recommend avoiding overall fit measures.

Table 2. Correlation matrix, Construct reliability and validity, Discriminant validity

\begin{tabular}{lllll|lll}
\hline & $\begin{array}{l}\text { Cronbac } \\
\text { h's } \\
\text { Alpha }\end{array}$ & $\begin{array}{l}\text { rho_ } \\
\text { A }\end{array}$ & $\begin{array}{l}\text { Composite } \\
\text { Reliability }\end{array}$ & $\begin{array}{l}\text { Average } \\
\text { Variance } \\
\text { Extracted } \\
\text { (AVE) }\end{array}$ & $\begin{array}{l}\text { External } \\
\text { organization } \\
\text { impact }\end{array}$ & $\begin{array}{l}\text { Headquarter } \\
\text { Benefit }\end{array}$ & $\begin{array}{l}\text { Internal } \\
\text { investme } \\
\text { nt }\end{array}$ \\
\hline $\begin{array}{l}\text { External } \\
\text { organization } \\
\text { impact }\end{array}$ & 0.81 & 0.834 & 0.877 & 0.643 & $\mathbf{0 . 8 0 2}$ & & \\
$\begin{array}{l}\text { Headquarter } \\
\text { Benefit } \\
\begin{array}{l}\text { Internal } \\
\text { investment }\end{array}\end{array}$ & 0.924 & 0.93 & 0.937 & 0.623 & 0.408 & $\mathbf{0 . 7 8 9}$ & \\
\hline
\end{tabular}

Note. Diagonal elements present the square root of the AVE (in bold)

\subsection{Analysis of structural model results}

The analysis of the structural model relies on the evaluation of the statistical significance of structural coefficients, as presented in the PLS model. Structural coefficients correspond to $\beta$ values in the Ordinary Least Squares regression (Henseler, Ringle, \& Sinkovics, 2009) but the bootstrap method (5,000 sub-samples; HernándezPerlines, Moreno-García, \& Yañez-Araque, 2016) was used instead. This model detects expatriates' perceptions of the impact of external organizations, and subsidiary investment affects headquarters' benefits. The relationship between expatriate perceptions on external organizations' impact on headquarters' benefits is positive and statistically significant $(\beta=.259 ; \mathrm{t}=2.299 ; \mathrm{p}<.05$; see Table 3$)$. This indicates that expatriate managers perceive that the growth of an external organization means that headquarters' benefits will increase as well. Furthermore, the model shows that subsidiary internal investment affect headquarters' benefits. The relationship between subsidiaries' investments and headquarters' benefits is positive, and statistically significant $(\beta=.268$; $\mathrm{t}=2.765 ; \mathrm{p}<.05$; see Table 3 ). This indicates that expatriate managers perceive that the growth of a subsidiary's internal investment leads to an increase in headquarters' benefits. Finally, controlling the number of previous expatriate assignments, we divided the sample into two sub-samples. The first sub-sample ( expatriate managers with one previous assignment, and the second sub-sample (size = $67 \%$ of total sample) consisted of expatriate managers with more than one previous assignment. The PLS-MGE method indicates that, with regards to the relationship between external organizations' impact and headquarters' benefits, the subsamples' differences were not statistically significant (see Table 4.). This means that there is not sufficient evidence to prove that the number of previous assignments determines this relationship, contrary to our expectations. Furthermore, these findings also indicate that 
the impact of subsidiaries' degree of internal investment on headquarters' benefits is not dependent on the number of previous assignments.

Table 3. Structural model analysis

\begin{tabular}{lllllc}
\hline & $\begin{array}{l}\text { Original } \\
\text { Sample } \\
(\mathrm{O})\end{array}$ & $\begin{array}{l}\text { Sample } \\
\text { Mean } \\
(\mathrm{M})\end{array}$ & $\begin{array}{l}\text { Standard } \\
\text { Deviation } \\
(\mathrm{STDEV})\end{array}$ & $\begin{array}{l}\text { T Statistics } \\
(|\mathrm{O} / \mathrm{STDEV}|)\end{array}$ & $\begin{array}{l}\mathrm{P} \\
\text { Values }\end{array}$ \\
\hline $\begin{array}{l}\text { External organization } \\
\text { impact -> Headquarter }\end{array}$ & 0.259 & 0.266 & 0.113 & 2.299 & 0.022 \\
$\begin{array}{l}\text { Benefit } \\
\begin{array}{l}\text { Internal investment -> } \\
\text { Headquarter Benefit }\end{array}\end{array}$ & 0.268 & 0.293 & 0.097 & 2.773 & 0.006 \\
\hline
\end{tabular}

Table 4. PLS-MGE (control variable test)

\begin{tabular}{llll}
\hline & $\begin{array}{l}\text { Path Coefficients-diff } \\
\text { (more than one } \\
\text { previous assignment }- \\
\text { one previous } \\
\text { assignment) }\end{array}$ & $\begin{array}{l}\text { p-Value original 1-tailed } \\
\text { (more than one previous } \\
\text { assignment vs one } \\
\text { previous assignment) }\end{array}$ & $\begin{array}{l}\text { p-Value new (more } \\
\text { than one previous } \\
\text { assignment vs one } \\
\text { previous assignment) }\end{array}$ \\
\hline $\begin{array}{l}\text { External } \\
\text { organization } \\
\text { impact -> }\end{array}$ & -0.223 & 0.781 & 0.439 \\
$\begin{array}{l}\text { Headquarter } \\
\text { Benefit }\end{array}$ & & & 0.464 \\
$\begin{array}{l}\text { Internal } \\
\text { investment }->\end{array}$ & 0.310 & 0.232 & \\
$\begin{array}{l}\text { Headquarter } \\
\text { Benefit }\end{array}$ & & & \\
\hline
\end{tabular}

\section{DISCUSSION AND CONCLUSION}

This study focuses on expatriate managers' perceptions of processes enveloped around MNCs' inter- and intra-organizational relationships. Expatriate managers perceive that external organizations' impact upon subsidiaries, as well as the internal investment subsidiaries undertake, have a positive impact on headquarters' knowledge bases. Findings from the first hypothesis indicate that expatriate managers perceive that the strong impact of external actors on a subsidiary's existing knowledge base - more precisely, market customers, market suppliers, specific distributors, and specific R\&D units - increases headquarters' benefits. These findings are in line with previous research conducted by Nell and Ambos (2013) and Holmström (2010), who demonstrate a positive relationship between headquarters' embeddedness and a subsidiary's context, emphasizing the potential overlapping of the relationships subsidiaries maintain with their networks (Nell, Ambos, \& Schlegelmilch, 2011). 'Headquarters involvement' (Ciabuschi, Dellestrand, and Martin, 2015), mostly refers to information exchange 
relationships, compared with the interaction intensive ones that subsidiaries nurture (Nell \& Ambos, 2013). This generally serves to fine-tune and coordinate global strategies (Ambos, Ambos, \& Schlegelmilch, 2006). Findings from the second hypothesis indicate that expatriate managers perceive subsidiaries' internal investments to be positively correlated with headquarters' benefits. This is in line with previous research conducted by Foss and Pedersen (2002) and confirms the positive relationship between subsidiary investment and knowledge transfer levels, focusing on the strong interdependence between subsidiaries and headquarters. This was later confirmed in research conducted by Jimenéz-Jimenéz, Martínez-Costa, and Sanz-Valle (2014), which emphasized the importance of transferring knowledge to headquarters. However, this finding was scrutinized by Mudambi, Pedersen, and Andersson (2014), who argued that subsidiary innovativeness is beneficial for headquarters only to a certain extent, beyond which increased innovativeness leads to less benefits. The results from this research provide strong empirical evidence in support of both developed hypotheses, and indicate that expatriate managers perceive the same determinants which constitute relevant knowledge in subsidiaries, and these are beneficial for headquarters as well. This phenomenon could be best explained through a philosophical pragmatism framework. "Pragmatism is the intellectual attitude related to action that consider thought more than a passive reflexion or representation of the reality" (Cojanu, 2014).

Expatriate managers consider their thoughts or perceptions as instruments for prediction, action, and problem solving. Perception is a belief or opinion (Cambridge Dictionary, 2020). Thus, they find their knowledge transfer actions to be more than just passive reflections or representations of their reality. Their knowledge transfer actions are the result of their perceptions of relevant and useful knowledge - those that provide valuable results (Cojanu, 2014). According to philosophical pragmatism, managers perceive knowledge to be relevant in terms of the impact it has on existing knowledge and the effort needed to process it (Schulz, 2003). In the context of this research, when perceiving the strong impact of external actors, such as market customers, market suppliers, specific distributors, and specific R\&D units, expatriate managers consider their input relevant to existing subsidiaries' business processes. Furthermore, subsidiaries' investments generate managerial capabilities for integration and recombination in order to embed the acquired knowledge into routines that are strongly intertwined with existing subsidiaries' and MNCs' routines (Foss \& Pedersen, 2002). Expatriate managers believe that this increases the likelihood of connections or links between providers and receivers of knowledge (Yang et al., 2008), lowering the effort needed to process knowledge. Thus, perceiving the impact of external knowledge and strong investments, expatriate managers will consider knowledge relevant and useful if it increases headquarters' benefits and is thus an instrument of reverse knowledge transfer.

\section{Theoretical implications}

This research considers perception to be an instrument of their actions, indicating that knowledge transfer is more than just a passive reflection or representation of their reality. Using philosophical pragmatism and highlighting the link between relevant knowledge and knowledge transfer actions, this study complements existing 
research on the role of expatriate managers' psychological components in the knowledge transfer process. Finally, demonstrating the importance of individual psychological components, this research opens up a call for future research examining psychological and sociological theories, models, and concepts that are relevant to the knowledge transfer phenomenon.

\section{Managerial implications}

These empirical findings lead expatriate managers, as well as headquarters, towards a better understanding of knowledge flow. Emphasizing the importance of external actors and knowledge base compatibility development, this research offers readers a better understanding of the importance of inter- and intra-organizational knowledge flow sequences. Furthermore, with knowledge flow sequence familiarity, readers are able to understand the importance of expatriate managers, as well as headquarters' management, when it comes to priority harmonization. Thus, this research directs MNCs' management teams to invest effort into profiling expatriate managers and educating them on global network relevance priorities before assignments. This research suggests that expatriate managers should focus their efforts on the development of interorganizational agreements with external partners and, in doing so, increase their contribution to internal MNCs' networks. Furthermore, with their freedom to manage subsidiaries' financial means, expatriate managers should put effort into directing financial means towards widening internal knowledge bases in order to increase subsidiaries' absorptive capacity and increase their propensity to use external knowledge.

\section{Limitations}

This paper explores relevance perception, beliefs, and subjective opinions on knowledge transfer actions. However, expats relevance perception priorities may be disrupted when headquarters impose performance evaluation criteria (O'Donnell, 2000). Fear of evaluation criteria is justified as a lack of compliance might result in them losing their job or having a lack of support and investment from their headquarters. Consequently, even though freedom exists, it might be constrained by the expectations of the headquarters. As with other research exploring individual psychological components, this paper is also subject to expatriate managers' experience limitations (Peruffo, Marchegiani, \& Vicentini, 2018), which decreases their likelihood of recognizing relevant knowledge.

\section{Further research}

Given that this research was conducted in one developing country sample Croatia - it opens up a call for other researchers to conduct the same research in other developing countries in order to confirm that Croatia does not represent an exception. Further research should focus on industry diversification in order to establish whether or not expatriate managers believe that their industries show specific trends. 


\section{REFERENCES:}

1. Afthanorhan, W. M. A. B. W. (2013). A comparison of partial least square structural equation modeling (PLS-SEM) and covariance based structural equation modelling (CB-SEM) for confirmatory factor analysis. International Journal of Engineering Science and Innovative Technology, 2(5), pp. 198-205.

2. Ambos, T. C., Ambos, B., and Schlegelmilch, B. B. (2006). Learning from foreign subsidiaries: An empirical investigation of headquarters' benefits from reverse knowledge transfers. International Business Review, 15(3), pp. 294-312.

3. Andersson, U., Björkman, I., and Forsgren, M. (2005). Managing subsidiary knowledge creation: The effect of control mechanisms on subsidiary local embeddedness. International Business Review, 14(5), 521-538.

4. Andersson, U., Dahlin, P., and Ekman, P. (2014). The Role of Internal Embeddedness for Subsidiary Influence in the Multinational Enterprise. In: European International Business Academy (EIBA), 40th Annual Conference, Uppsala University, Sweden, December 11-13, 2014.

5. Andersson, U., Forsgren, M., and Holm, U. (2002). The strategic impact of external networks: subsidiary performance and competence development in the multinational corporation. Strategic management journal, 23(11), pp. 979-996.

6. Anzola Román, P., Bayona Sáez, C., Marco, G., Teresa, M., and Lazzarotti, V. (2019). Technological proximity and the intensity of collaboration along the innovation funnel: direct and joint effects on innovative performance. Journal of Knowledge Management, 23 (5), pp. 931-952.

7. Asmussen, C. G., Foss, N. J., and Pedersen, T. (2013). Knowledge transfer and accommodation effects in multinational corporations: Evidence from European subsidiaries. Journal of Management, 39(6), pp. 1397-1429.

8. Barclay, D. W., Higgins, C., and Thomson, R. (1995). The partial least squares (pls) approach to casual modeling: Personal computer adoption and use as an illustration. Technology Studies, 2(2), pp. 285-309

9. Bartlett, C. A. and Rangan, S. U. (1992). Kentucky Fried Chicken ( Japan) Limited. Boston, MA: Harvard Business School Press

10. Bartlett, C. A., and St. George, A. (1998) "Acer America: Development of the Aspire." Harvard Business School Case 399-011, January 1998.

11. Birkinshaw, J., and Hood, N. (1998). Multinational subsidiary evolution: Capability and charter change in foreign-owned subsidiary companies. Academy of management review, 23(4), pp. 773-795.

12. Björkman, I., Barner-Rasmussen, W., and Li, L. (2004). Managing knowledge transfer in MNCs: The impact of headquarters control mechanisms. Journal of international business studies, 35(5), pp. 443-455.

13. Bouquet, C., and Birkinshaw, J. (2008). Weight versus voice: How foreign subsidiaries gain attention from corporate headquarters. Academy of Management journal, 51(3), pp. 577-601.

14. Brewer, J., and Staves, S. (Eds.). (2014). Early modern conceptions of property (Vol. 2). Routledge. 
15. Buckley, P. J., and Strange, R. (2011). The governance of the multinational enterprise: Insights from internalization theory. Journal of Management Studies, 48(2), pp. 460-470.

16. Cantwell, J., and Mudambi, R. (2005). MNE competence-creating subsidiary mandates. Strategic management journal, 26(12), pp. 1109-1128.

17. Cambridge Dictionary 2020, 'Meaning of perception', available at: https://dictionary.cambridge.org/dictionary/english/perception (accessed 21 March 2020)

18. Chang, Y. Y., Gong, Y., and Peng, M. W. (2012). Expatriate knowledge transfer, subsidiary absorptive capacity, and subsidiary performance. Academy of Management Journal, 55(4), pp. 927-948.

19. Chiao, Y. C., and Ying, K. P. (2013). Network effect and subsidiary autonomy in multinational corporations: An investigation of Taiwanese subsidiaries. International Business Review, 22(4), pp. 652-662.

20. Chin, W. W. (1998). The partial least squares approach to structural equation modeling. Modern Methods for Business Research, 295(2), 295-336.

21. Ciabuschi, F., Dellestrand, H., and Martín, O. M. (2015). Internal embeddedness, headquarters involvement, and innovation importance in multinational enterprises. In Knowledge, Networks and Power (pp. 284-317). Palgrave Macmillan, London.

22. Cojanu, D. (2014). Philosophical pragmatism and social action today. Postmodern Openings, 5(1), pp. 9-10.

23. Compeau, D. R., and Huff, S. (1999). Social cognitive theory and individual reactions to computing technology: A longitudinal study. MIS Quarterly, 23, $145-158$.

24. Cricelli, L., and Grimaldi, M. (2010). Knowledge-based inter-organizational collaborations. Journal of Knowledge Management.

25. Cuervo-Cazurra, A., Mudambi, R., and Pedersen, T. (2019). Clarifying the relationships between institutions and global strategy. Global Strategy Journal, 9(2), 151-175.

26. Darawong, C., Igel, B., and Badir, Y. F. (2016). The impact of communication on conflict between expatriate and local managers working in NPD projects of MNC subsidiaries: A local perspective. Journal of Asia-Pacific Business, 17(1), 81-99.

27. Davis, L. N., and Meyer, K. E. (2004). Subsidiary research and development, and the local environment. International Business Review, 13(3), 359-382.

28. Dhanaraj, C., and Beamish, P. W. (2009). Institutional environment and subsidiary survival. Management International Review, 49(3), 291-312.

29. Dörrenbächer, C., and Gammelgaard, J. (2016). Subsidiary initiative taking in multinational corporations: the relationship between power and issue selling. Organization Studies, 37(9), 1249-1270.

30. Epstein, G. (2019). The role and control of multinational corporations in the world economy. In The Handbook of Globalisation, Third Edition. Edward Elgar Publishing. 
31. Evans, D., Rees, M., and Edwards, R. (2017). The influence of subsidiary strategic role on manager's mindset. Electronic Journal of Business \& Management, 2(1), 11-28.

32. Fang, Y., Jiang, G. L. F., Makino, S., and Beamish, P. W. (2010). Multinational firm knowledge, use of expatriates, and foreign subsidiary performance. Journal of Management Studies, 47(1), 27-54.

33. Ferner, A., Edwards, T., and Tempel, A. (2012). Power, institutions and the cross-national transfer of employment practices in multinationals. Human relations, 65(2), 163-187.

34. Figueiredo, P. N. (2011). The role of dual embeddedness in the innovative performance of MNE subsidiaries: evidence from Brazil. Journal of management studies, 48(2), 417-440.

35. Fornell, C., and Larcker, D. F. (1981). Evaluating structural equation models with unobservable variables and measurement error. Journal of Marketing Research, 18(1), 39-50.

36. Forsgren, M., Holm, U., and Johanson, J. (2007). Managing the embedded multinational: A business network view. Edward Elgar Publishing.

37. Foss, N. J., and Pedersen, T. (2002). Transferring knowledge in MNCs: The role of sources of subsidiary knowledge and organizational context. Journal of International Management, 8(1), 49-67.

38. Galunic, D. C., and Eisenhardt, K. M. (1994). Renewing the strategy-structureperformance paradigm. Research in organizational behavior, 16, 215-215.

39. Garcia-Pont, C., Canales, J. I., and Noboa, F. (2009). Subsidiary strategy: The embeddedness component. Journal of Management Studies, 46(2), 182-214.

40. Gaur, A. S., Delios, A., and Singh, K. (2007). Institutional environments, staffing strategies, and subsidiary performance. Journal of Management, 33(4), 611-636.

41. Ghobadi, S., and Mathiassen, L. (2016). Perceived barriers to effective knowledge sharing in agile software teams. Information systems journal, 26(2), 95-125.

42. Gupta, A. K., and Govindarajan, V. (2002). Cultivating a global mindset. Academy of Management Perspectives, 16(1), 116-126.

43. Hair, J. F., Hult, G. T. M., Ringle, C. M., and Sarstedt, M. (2017). A primer on partial least squares structural equation modeling (2nd edition). Thousand Oaks, CA: Sage Publications.

44. Hair, J., Black, W., Babin, B., and Anderson, R. (2010). Multivariate data analysis: A global perspective. Upper Saddle River, New Jersey, SAD: Pearson Education.

45. Harzing, A. W., and Pudelko, M. (2014). Hablas vielleicht un peu la mia language? A comprehensive overview of the role of language differences in headquarters-subsidiary communication. The International Journal of Human Resource Management, 25(5), 696-717.

46. Henseler, J., and Sarstedt, M. (2013). Goodness-of-fit indices for partial least squares path modeling. Computational Statistics, 28(2), 565-580 
47. Henseler, J., Ringle, C. M., and Sinkovics, R. R. (2009). The use of partial least squares path modeling in international marketing. Advances in International Marketing, 20, 277-319.

48. Hernández-Perlines, F., Moreno-García, J., and Yañez-Araque, B. (2016). The mediating role of competitive strategy in international entrepreneurial orientation. Journal of Business Research, 69(11), 5383-5389

49. Ho, H., and Ganesan, S. (2013). Does knowledge base compatibility help or hurt knowledge sharing between suppliers in coopetition? The role of customer participation. Journal of Marketing, 77(6), 91-107.

50. Holl, A., and Rama, R. (2014). Foreign subsidiaries and technology sourcing in Spain. Industry and Innovation, 21(1), 43-64.

51. Holmström, C. (2010). Managing the transfer of externally embedded subsidiary knowledge: The role of headquarters' control mechanisms. Managing the contemporary multinational: The role of headquarters. Northampton, MA: Edward Elgar, 231-253.

52. Inkpen, A. C., and Dinur, A. (1998). Knowledge management processes and international joint ventures. Organization science, 9(4), 454-468.

53. Jimenéz-Jimenéz, D., Martínez-Costa, M., and Sanz-Valle, R. (2014). Innovation, organizational learning orientation and reverse knowledge transfer in multinational companies. Electronic Journal of Knowledge Management, 12(1), 47-55.

54. Kline, R. B. (2011). Principles and practices of structural equation modeling (Third edition).

55. Kobrin, S. J. (1988). Expatriate reduction and strategic control in American multinational corporations. Human resource management, 27(1), 63-75.

56. Koo Moon, H., Kwon Choi, B., and Shik Jung, J. (2012). Previous international experience, cross-cultural training, and expatriates' cross-cultural adjustment: Effects of cultural intelligence and goal orientation. Human Resource Development Quarterly, 23(3), 285-330.

57. Kostova, T., and Zaheer, S. (1999). Organizational legitimacy under conditions of complexity: The case of the multinational enterprise. Academy of Management review, 24(1), 64-81.

58. Kostova, T., Marano, V., and Tallman, S. (2016). Headquarters-subsidiary relationships in MNCs: Fifty years of evolving research. Journal of World Business, 51(1), 176-184.

59. Kumar, N. (2013). Managing reverse knowledge flow in multinational corporations. Journal of Knowledge Management, Vol. 17 No. 5, pp. 695-708

60. Kusumato, M. (2014). The role of expatriates in cross-subsidiary collaboration. In Collaboration for Sustainability and Innovation: A Role For Sustainability Driven by the Global South? (pp. 43-62). Springer, Dordrecht.

61. Lee, L. Y., and Kartika, N. (2014). The influence of individual, family, and social capital factors on expatriate adjustment and performance: The moderating effect of psychology contract and organizational support. Expert Systems with Applications, 41(11), 5483-5494. 
62. Levy, O., Beechler, S., Taylor, S., and Boyacigiller, N. A. (2007). What we talk about when we talk about 'global mindset': Managerial cognition in multinational corporations. Journal of International Business Studies, 38(2), 231-258.

63. Levin, D. Z., \& Cross, R. (2004). The strength of weak ties you can trust: The mediating role of trust in effective knowledge transfer. Management science, 50(11), 1477-1490.

64. Lim, M., and Yeo, J. (2015). Reshoring pattern-analysis of China based Korean firms and its policy implications. KIEP Research Paper No. World Economy Update-15-03.

65. Mesquita, L. F., Anand, J., and Brush, T. H. (2008). Comparing the resourcebased and relational views: knowledge transfer and spillover in vertical alliances. Strategic management journal, 29(9), 913-941.

66. Meyer, K. E., and Estrin, S. (2014). Local context and global strategy: Extending the integration responsiveness framework to subsidiary strategy. Global Strategy Journal, 4(1), 1-19.

67. Michailova, S., and Minbaeva, D. B. (2012). Organizational values and knowledge sharing in multinational corporations: The Danisco case. International Business Review, 21(1), 59-70.

68. Mikalef, P., and Pateli, A. (2017). Information technology-enabled dynamic capabilities and their indirect effect on competitive performance: Findings from PLS-SEM and fsQCA. Journal of Business Research, 70, 1-16.

69. Milgram, S., Sabini, J. E., and Silver, M. E. (1992). The individual in a social world: Essays and experiments. Mcgraw-Hill Book Company.

70. Minbaeva, D. B., and Michailova, S. (2004). Knowledge transfer and expatriation in multinational corporations. Employee relations.

71. Ministry of Internal Affairs (2014) Official Gazette, no. 130/11 and 74/13

72. Mudambi, R., Pedersen, T., and Andersson, U. (2014). How subsidiaries gain power in multinational corporations. Journal of World Business, 49(1), 101-113.

73. Nell, P. C., and Ambos, B. (2013). Parenting advantage in the MNC: An embeddedness perspective on the value added by headquarters. Strategic Management Journal, 34(9), 1086-1103.

74. Nell, P. C., Ambos, B., and Schlegelmilch, B. B. (2011). The MNC as an externally embedded organization: An investigation of embeddedness overlap in local subsidiary networks. Journal of World Business, 46(4), 497-505.

75. Nunnally, J. C., and Bernstein, I. H. (1994). The assessment of reliability. Psychometric theory, 3(1), 248-292.

76. O’Donnell, S. W. (2000). Managing foreign subsidiaries: agents of headquarters, or an interdependent network?. Strategic management journal, 21(5), 525-548.

77. Oddou, G., Osland, J. S., and Blakeney, R. N. (2009). Repatriating knowledge: Variables influencing the "transfer" process. Journal of international business studies, 40(2), 181-199. 
78. Palich, L. E., and Gomez-Mejia, L. R. (1999). A theory of global strategy and firm efficiencies: Considering the effects of cultural diversity. Journal of management, 25(4), 587-606.

79. Peltokorpi, V., and Vaara, E. (2014). Knowledge transfer in multinational corporations: Productive and counterproductive effects of language-sensitive recruitment. Journal of International Business Studies, 45(5), 600-622.

80. Perlmutters, H. V. (1969). Some Management Problems In Spaceship Earth: The Megafirm And The Global Industrial Estate. In Academy of Management Proceedings (Vol. 1969, No. 1, pp. 59-87). Briarcliff Manor, NY 10510: Academy of Management.

81. Peruffo, E., Marchegiani, L. and Vicentini, F. (2018), "Experience as a source of knowledge in divestiture decisions: emerging issues and knowledge management implications", Journal of Knowledge Management, Vol. 22 No. 2, pp. 344-361.

82. Phene, A., and Almeida, P. (2008). Innovation in multinational subsidiaries: The role of knowledge assimilation and subsidiary capabilities. Journal of international business studies, 39(5), 901-919.

83. Porter, M. E., and Sölvell, O. (1998). The role of geography in the process of innovation and sustainable competitive advantage of firms.

84. Pudelko, M., and Harzing, A. W. (2008). The golden triangle for MNCs: Standardization towards headquarters practices, standardization towards global best practices and localization. Organizational dynamics, 37(4), 394-404.

85. Ringle, C. M., Wende, S., and Will, A. (2017). SmartPLS v. 3.2.6. Hamburg: SmartPLS. available at www.smartpls.de.

86. Riusala, K., and Smale, A. (2007). Predicting stickiness factors in the international transfer of knowledge through expatriates. International studies of management \& organization, 37(3), 16-43.

87. Riusala, K., and Suutari, V. (2004). International knowledge transfers through expatriates. Thunderbird International Business Review, 46(6), 743-770.

88. Rugman, A. M., and D'Cruz, J. R. (2000). The theory of the flagship firm. Cooperative strategy: economic, business and organizational issues, 5773.

89. Ryan, P., Giblin, M., Andersson, U., and Clancy, J. (2018). Subsidiary knowledge creation in co-evolving contexts. International Business Review, 27(5), 915-932.

90. Sanchez-Vidal, M. E., Sanz-Valle, R., and Barba-Aragon, M. I. (2018). Repatriates and reverse knowledge transfer in MNCs. The International Journal of Human Resource Management, 29(10), 1767-1785.

91. Santangelo, G. D., Meyer, K. E., and Jindra, B. (2016). MNE subsidiaries' outsourcing and insourcing of R\&D: The role of local institutions. Global Strategy Journal, 6(4), 247-268.

92. Schulz, M. (2003). Pathways of relevance: Exploring inflows of knowledge into subunits of multinational corporations. Organization Science, 14(4), 440-459. 
93. Serenko, A., and Bontis, N. (2016). Negotiate, reciprocate, or cooperate? The impact of exchange modes on inter-employee knowledge sharing. Journal of Knowledge Management. Vol. 20 No. 4, pp. 687-712

94. Shaffer, M. A., Reiche, B. S., Dimitrova, M., Lazarova, M., Chen, S., Westman, M., and Wurtz, O. (2016). Work-and family-role adjustment of different types of global professionals: Scale development and validation. Journal of International Business Studies, 47(2), 113-139.

95. Simao, L., and Franco, M. (2018). External knowledge sources as antecedents of organizational innovation in firm workplaces: a knowledge-based perspective. Journal of Knowledge Management. Vol. 22 No. 2, pp. 237-256

96. Sitar, A. S., and Mihelič, K. K. (2018). The interplay of expatriates' psychological and social capital for knowledge transfer, Economic and Business Review for Central and South-Eastern Europe, 20(2), 195-306.

97. Syed, J., Hazboun, N. G., and Murray, P. A. (2014). What locals want: Jordanian employees' views on expatriate managers. The International Journal of Human Resource Management, 25(2), 212-233.

98. Szulanski, G. (1996). Exploring internal stickiness: Impediments to the transfer of best practice within the firm. Strategic management journal, 17(S2), 27-43.

99. Teece, D. J. (1977). Technology transfer by multinational firms: The resource cost of transferring technological know-how. The economic journal, 87(346), 242-261.

100.Tenenhaus, M., Vinzi, V. E., Chatelin, Y. M., and Lauro, C. (2005). PLS path modeling. Computational statistics \& data analysis, 48(1), 159-205.

101.Tseng, C. H., and Chen, L. T. (2014). Determinants of subsidiary's technological capability-examining the roles of subsidiary-local supplier linkage. Journal of Business \& Industrial Marketing.

102.Welch, D. E., and Welch, L. S. (2008). The importance of language in international knowledge transfer. Management International Review, 48(3), 339-360.

103.Windsperger, J., and Gorovaia, N. (2011). Knowledge attributes and the choice of knowledge transfer mechanism in networks: the case of franchising. Journal of Management \& Governance, 15(4), 617-640.

104. Yamin, M., and Andersson, U. (2011). Subsidiary importance in the MNC: What role does internal embeddedness play?. International Business Review, 20(2), 151-162.

105.Yang, Q., Mudambi, R., and Meyer, K. E. (2008). Conventional and reverse knowledge flows in multinational corporations. Journal of Management, 34(5), 882-902.

106.Yi, M. Y., and Davis, F. D. (2003). Developing and validating an observational learning model of computer software training and skill acquisition. Information Systems Research, 14(2), 146-169.

107.Zhou, Z., Zhang, Q., Su, C., and Zhou, N. (2012). How do brand communities generate brand relationships? Intermediate mechanisms. Journal of Business Research, 65(7), 890-895. 


\title{
RELEVANTNOST ZNANJA KAO INSTRUMENT ZA USPJEŠNO DJELOVANJE EKSPATRIJATA
}

\author{
Davor Vlajčić
}

\section{Sažetak}

Svrha: Ovaj rad istražuje filozofiju globalnih tokova znanja multinacionalnih kompanija, fokusirajući se na adsorpciju znanja od vanjskih aktera te aktivnosti ekspatrijata. Primjenjujući filozofski pragmatizam kao teorijsku pozadinu, percepcija ekspatrijata predstavljena je kao alat koji omogućava uspješan prijenos znanja.

Dizajn/Metodologija/Pristup: Korišteni su podaci prikupljeni anketnim upitnikom na uzorku ekspatrijata u Republici Hrvatskoj. Za izračun korelacije vanjskih aktera, odnosno investicija podružnice $i$ koristi središnjice, primijenjena je metoda parcijalnih strukturnih jednadžbi.

Rezultati i implikacije: Ekspatrijati smatraju kako koristi za središnjicu multinacionalne kompanije dolaze od snažnijeg utjecaja vanjskih aktera na podružnicu te rasta investicija podružnica. Rezultati upućuju na nužnost harmonizacije prioriteta podružnice i središnjice. Također, naglašava važnost proširivanja inter-organizacijske ali i intra-organizacijske suradnje ulaganjem u rast interne baze znanja.

Ograničenja: Ovaj rad oslanja se na istraživanje percepcije ekspatrijata o relevantnosti znanja s kojim se susreću, međutim, uvođenjem evaluacijskih kriterija od strane središnjice, prioriteti expatrijata mogu biti nametnuti, te njihova percepcija može izgubiti na važnosti. Također, limitirano iskustvo ekspatrijata može utjecati sposobnost fokusiranja na važno znanje.

Originalnost rada: Fokusirajući se na psihološku komponentu expatriajata, ovaj rad uvodi filozofski pragmatizam kao teoretski okvir za uspješan transfer znanja. Potječući iz pragmatizma, uspješni potezi rezultat su percepciju relevantnog znanja menadžera. Postupci ekspatrijata nisu pasivni odraz njihove stvarnosti, već rezultat percepcije relevantnog znanja.

Ključne riječi: pragmatizam, podružnica, središnjica, ekpatrija menadžeri, relevantno znanje, percepcija. 